\title{
PROSPEK PENGEMBANGAN USAHATANI PADI GOGO PADA PROGRAM PENGELOLAAN HUTAN BERSAMA MASYARAKAT (PHBM) DI DESA JATIMUNGGUL, KECAMATAN TERISI, KABUPATEN INDRAMAYU
}

\author{
Kuswarini Kusno ${ }^{1}$, Linda Wulandari ${ }^{2}$, dan Eti Suminartika ${ }^{1}$ \\ ${ }^{1}$ Departemen Sosial Ekonomi Pertanian, Fakultas Pertanian, Universitas Padjadjaran \\ ${ }^{2}$ Alumni Program Studi Agribisnis, Fakultas Pertanian, Universitas Padjadjaran \\ Email: Kuswarini.kusno@unpad.ac.id
}

\begin{abstract}
ABSTRAK
PHBM adalah suatu sistem pengelolaan sumberdaya hutan yang dilakukan bersama oleh Perum. Perhutani dan masyarakat desa hutan. Salah satu desa yang melaksanakan program tersebut adalah Desa Jatimunggul. Dalam pelaksanaannya pihak masyarakat desa sekitar hutan tidak setuju dengan adanya pengambilalihan kekuasaan pengelolaan hutan oleh pihak Perhutani. Akibatnya petani protes mengenai lahan hutan yang dianggap sebagai lahan milikinya.Tujuan penelitian ini adalah untuk mengetahui keragaan usahatani padi gogo dan prospek pengembangannya. Desain penelitian adalah kualitatif dengan teknik penelitian studi kasus. Hasil penelitian menunjukkan bahwa budidaya padi gogo program PHBM di Desa Jatimunggul masih menggunakan alat-alat sederhana. Modal diperoleh sebagian besar dari pinjaman ke tengkulak. Perencanaan lokasi dan komoditas melibatkan Perhutani. Pemasaran hasil melibatkan tengkulak. Rata-rata penerimaan per hektar per musim tanam per tahun adalah Rp. 23.800.333 sedangkan pendapatannya Rp. 9.402 .985 dengan rata-rata hasil produksi $3.543 \mathrm{~kg} / \mathrm{ha}$. Rata-rata biaya total adalah Rp. 15.112 .352 yang terdiri dari biaya variabel Rp. 14.480.450 dan biaya tetap Rp. 631.902. Dibandingkan dengan penerimaan padi gogo di Desa Sukasari Kabupaten Subang tahun 2014, penerimaan padi gogo di Desa Jatimunggul adalah 45\% lebih besar. Program PHBM memberi manfaat ekonomi berupa usahatani padi gogo yang menguntungkan dan manfaat sosial berupa penyediaan lapangan pekerjaan, sehingga usahatani ini memiliki prospek untuk dikembangkan.
\end{abstract}

Katakunci: PHBM, usahatani, padi gogo

\begin{abstract}
PHBM is a system of forest resources management conducted jointly by "Perum". Perhutani and forest village community. One of the villages that implement the program is Jatimunggul Village. In practice, the villagers around the forest do not agree with the takeover of forest management power by Perhutani. As a result, farmers protest about the forest land they consider as their own land. The aim of this study is to identify the performance of upland rice farming and its development prospects. The research design was qualitative supported by quantitative data with case study research technique. The results showed that the cultivation of upland rice in the PHBM Program in Jatimunggul Village still used simple tools. Capital was obtained mostly from loans to middlemen. Location and commodity planning involved Perhutani. Marketing of upland rice involved middlemen. The average revenue per hectare per planting season per year was IDR 23,800,333 while the income was IDR 9,402,985 with an average production of 3,543 $\mathrm{kg} / \mathrm{ha}$. Average total cost was IDR. 15,112,352 consisting of variable cost IDR 14,480,450 and fixed cost IDR 631,902.

Compared with the revenue of upland rice in Sukasari Village, Subang Regency in 2014, the revenue of upland rice in Jatimunggul Village was $45 \%$ larger. PHBM programs provide economic benefits in the form of profitable upland rice farming and social benefits in the form of employment provision. Therefore, the upland rice farming in Jatimunggul Village is prospective to be developed.
\end{abstract}

Keywords: PHBM, farming, upland rice 


\section{PENDAHULUAN}

Hutan merupakan salah satu sektor penting dan mempunyai nilai stategis bagi pembangunan nasional mengingat hampir $67 \%$ luas daratan Indonesia berupa hutan (Dephut, 2008). Selain mempunyai nilai strategis bagi pembangunan nasional, hutan dengan keanekaragaman hayati berupa flora dan faunamemberikan berbagai manfaat bagi masyarakat.

Pola-pola pemanfaatan hutan tersebut beragam, mulai dari memanen hasil hutan baik flora maupun fauna hingga mengusahakan lahan hutan untuk kegiatan berusahatani. Kegiatan pertanian yang dilakukan oleh masyarakat pun sangat sederhana dan umumnya sudah dilakukan dalam bentuk pertanian menetap dengan mengembangkan kultivar unggul sebagai sumber pangan (Dephut, 2009). Pemanfaatan hutan secara terus-menerus tersebut dapat menyebabkan masyarakat di dalam dan sekitar hutan mengalami ketergantungan terhadap hutan.

Tuntutan ekonomi menyebabkan pemanfaatan hutan secara berlebihan yang mengakibatkan penurunan dan kerusakan sumberdaya hutan tersebut. Untuk mengurangi laju penurunan dan kerusakan tersebut, Perusahaan Umum (Perum) Perhutani selaku pengelola hutan menerapkan kebijakan untuk ikut memberdayakan masyarakat di dalam dan sekitar hutan dalam pengelolaan hutan melalui Sistem Pengelolaan Hutan Bersama Masyarakat (PHBM).

Dalam melaksanakan PHBM ini perlu suatu lembaga berbadan hukum yang menjadi representasi masyarakat desa untuk pengikatan kerjasama dengan Perhutani. Dengan demikian, petani yang melakukan usahatani secara tumpangsari di kawasan hutan tersebut disatukan dan dibentuk menjadi suatu lembaga yang selanjutnya disebut Lembaga Masyarakat Desa Hutan (LMDH).

Petani yang telah tergabung selanjutnya dapat menanam tanaman apapun selama tanaman yang mereka tanam tidak mengganggu tanaman pokok Perhutani. Komoditas yang paling banyak ditanam petani secara tumpangsari di kawasan hutan adalah padi. Tanaman padi dipilih oleh petani karena untuk pemenuhan kebutuhan pangannya sendiri akibat terbatasnya atau tidak adanya lahan pertanian yang mereka miliki yang disebabkan oleh banyaknya alih fungsi lahan yang terjadi di lahan pertanian khususnya sawah. Penurunan luas area sawah paling banyak terjadi di Pulau Jawa khususnya Jawa Barat (Statistik Lahan Pertanian, 2013). Memperhatikan situasi dan kondisi tersebut di atas, penanaman padi secara tumpangsari di kawasan hutan menjadi salah satu potensi untuk dapat memenuhi kebutuhan pangan rumah tangga petani yang tinggal di sekitar hutan. Menurut Dinas Kehutanan Propinsi Jawa Barat, (2014), Kesatuan Pemangku Hutan (KPH) Indramayu memiliki luas lahan paling besar dan produksi padi paling tinggi dibandingkan KPH lainnya. Hal ini disebabkan Kabupaten Indramayu merupakan salah satu sentra penanaman padi, sehingga petaninya banyak yang mengusahakan padi walaupun pada lahan kering (padi gogo) seperti di kawasan hutan. Selain itu, penanaman padi dilakukan karena KPH Indramayu memiliki hutan kayu putih yang luas, terutama di Desa Jatimunggul Kecamatan Terisi Kabupaten Indramayu. Petani yang melakukan kegiatan usahatani di desa tersebut tergabung dalam LMDH yang bernama LMDH Wana Makmur.

Pelaksanaan PHBM di Desa Jatimunggul masih mengalami kendala. Salah satunya adalah terjadi konflik antara pihak Perhutani dengan petani mengenai pengakuan lahan sebagai lahan pribadi. Hal tersebut menyebabkan terjadinya pengrusakan terhadap tanaman milik Perhutani di lokasi-lokasi yang digugat.

Tujuan penelitian ini adalah mengetahui keragaan usahatani padi gogo pada Program PHBM di Desa Jatimunggul, Kecamatan Terisi, Kabupaten Indramayu dan prospek pengembangannya.

\section{METODE PENELITIAN}

Penelitian ini menggunakan desain kualitatif yang didukung oleh data kuantitatif, dengan teknik studi kasus.

Data yang dikumpulkan merupakan data primer tahun 2015 dan sekunder. Data primer diperoleh melalui wawancara langsung dengan informan yang dipilih secara puruposif, yaitu kepala bidang PHBM, ketua dan 40 petani anggota LMDH Wana Makmur, serta Asisten Perhutan (Asper) BKPH Jatimunggul. Data sekunder diperoleh dari pustaka dan lembaga yang terkait dengan penelitian.

Alasan memilih informan-informan tersebut di atas dapat dijelaskan sebagai berikut: 
1. Kepala Bidang PHBM memiliki otoritas dan tanggung jawa langsung dalam program PHBM.

2. Ketua LMDH Wana Makmur berkoordinasi langsung dengan Perum. Perhutani.

3. Petani anggota LMDH Wana Makmur merupakan petani padi gogo di lahan milik Perum. Perhutani.

4. Asisten Perhutani BKPH Jatimunggul merupakan pejabat tertinggi di BKPH Jatimunggul.

Berikut ini adalah tahapan analisis data yang dilakukan:

1. Membuat tabel frekuensi variabel-variabel keragaan padi gogo.

2. Menganalisis prospek pengembangan usahatani dengan menghitung penerimaan, pendapatan petani dan rasio RC sebagai berikut:

a) Penerimaan usahatani menurut

Soekartawi (2002):

$$
\mathrm{TR}=\mathrm{P} \times \mathrm{Q}
$$

dimana:

$$
\begin{array}{ll}
\mathrm{TR}= & \begin{array}{l}
\text { Total Penerimaan }(\text { Total Revenue }) \\
(\mathrm{Rp}) \text { per musim tanam per tahun }
\end{array} \\
\mathrm{Q}= & \begin{array}{l}
\text { Quantity }(\mathrm{Kg}) \text { per musim } \\
\text { Tanam per tahun }
\end{array} \\
\mathrm{P}= & \begin{array}{l}
\text { Harga }(\text { Price }) \text { per satuan produk } \\
(\mathrm{Rp} / \mathrm{Kg}) \text { per musim tanam per tahun }
\end{array}
\end{array}
$$

b) Pendapatan petani menurut Rodjak (2006:81) yaitu:

$$
\pi=\mathrm{TR}-\mathrm{TC}
$$

dimana:

$\pi=$ Pendapatan per musim tanam per tahun

$\mathrm{TC}=$ Biaya total per musim tanam per Tahun

c) Pendapatan Usahatani menurut Hernanto (1989)

d) Rasio RC (Soekartawi, 2002):

$$
\mathrm{R} / \mathrm{C}=\mathrm{TR} / \mathrm{TC}
$$

Jika R/C > 1, berarti usahatani untung; jika $\mathrm{R} / \mathrm{C}=1$, berarti usahatani tidak untung dan juga tidak rugi; jika $\mathrm{R} / \mathrm{C}<1$, berarti usahatani tidak untung atau dengan kata lain, rugi.

\section{HASIL DAN PEMBAHASAN}

\section{Keadaan Umum KPH Indramayu.}

Perum Perhutani KPH Indramayu memiliki wilayah kerja mencakup kawasan hutan seluas 40.653,41 ha. Untuk pelaksanaan pengawasan di lapangan KPH Indramayu terbagi menjadi 5 Bagian Kesatuan Pemangku Hutan (BKPH) yaitu BKPH Jatimunggul, Cikawung, Plosok kerep, Sanca, dan Haur Geulis. Luas kawasan hutan yang berada di Desa Jatimunggul yaitu $2.612,48$ Ha yang ditanam tanaman kayu putih. Hutan pangkuan Desa Jatimunggul terbagi kedalam $2 \mathrm{BKPH}$ yaitu $\mathrm{BKPH}$ Plosokerep dan BKPH Jatimunggul.

\section{Program PHBM di Desa}

Jatimunggul. Desa Jatimunggul mempunyai luas wilayah yaitu 262.355 hektar yang terdiri dari 7 Rukun Warga (RW) dan 32 Rukun Tetangga (RT). Jarak tempuh dari Desa Jatimunggul ke ibu kota kecamatan yaitu 7,4 km sedangkan ke ibu kota Kabupaten Indramayu adalah $35,4 \mathrm{~km}$.

Pembuatan Perjanjian Kerjasama

Program PHBM. Perjanjian Kerjasama Program PHBM di Desa Jatimunggul pertama kali dilaksanakan pada tanggal 22 September 2006. Perjanjian kerjasama tersebut kemudian dituangkan dalam lembar perjanjian kerjasama yang disepakati oleh Perhutani KPH Indramayu dan LMDH Desa Jatimunggul. Masa berlaku perjanjian kerjasama tersebut adalah 10 tahun terhitung sejak penandatanganan perjanjian tersebut dan jika waktu perjanjian ini telah berakhir, maka dapat diadakan pembaruan perjanjian kembali sesuai dengan kesepakatan kedua belah pihak.

Tabel 1.

Pendapatan Usahatani Padi Gogo

\begin{tabular}{ll}
\hline \multicolumn{1}{c}{ Uraian } & \multicolumn{1}{c}{ Keterangan } \\
\hline A. Penerimaan tunai & $\begin{array}{l}\text { Harga } \mathrm{x} \text { hasil panen yang } \\
\text { dijual }\end{array}$ \\
$\begin{array}{l}\text { B. Penerimaan } \\
\text { diperhitungkan }\end{array}$ & $\begin{array}{l}\text { Harga } \mathrm{x} \text { hasil panen yang } \\
\text { dikonsumsi }\end{array}$
\end{tabular}

C. Total penerimaan

D. Pengeluaran tunai

$$
\mathrm{A}+\mathrm{B}
$$

a. Biayasaranaproduksi

- Pembelian benih

- Pembelian pupuk

- Pembelian pestisida

b. Upah tenaga kerja luar keluarga

E. Pengeluaran c. Bunga pinjaman diperhitungkan

a. Upah tenaga kerja dalam keluarga b. Nilai penyusutan alat c. Benih d. Sewa lahan

$\begin{array}{ll}\text { F. Total pengeluaran } & \mathrm{D}+\mathrm{E} \\ \begin{array}{l}\text { G. Pendapatan atas } \\ \text { biaya total }\end{array} & \mathrm{C}-\mathrm{F} \\ \begin{array}{l}\text { H. Pendapatan atas } \\ \text { biaya tunai }\end{array} & \mathrm{C}-\mathrm{D}\end{array}$


Desa Jatimunggul berada pada ketinggian sekitar 15 meter diatas permukaan laut (mdpl) dengan permukaan tanahnya berupa daratan dengan kemiringan antara 0 $2 \%$. Keadaan ini berpengaruh terhadap drainase, bila curah hujan tinggi maka akan terjadi genangan air dan bila musim kemarau akan mengakibatkan kekeringan. Dari segi tipe iklim termasuk iklim tropis, menurut klasifikasi Schmidt dan Ferguson termasuk iklim tipe D (iklim sedang) dengan karakteristik iklim antara lain: suhu udara harian berkisar antara $27^{\circ} \mathrm{C}-34^{\circ} \mathrm{C}$, kelembaban udara antara 70-80\%, curah hujan tahun 2013 sebesar $806 \mathrm{~mm}$ per tahun, dengan jumlah hari hujan sebanyak 76 hari.

\section{Kelembagaan dalam Program}

PHBM. Kelembagaan dalam program PHBM di Desa Jatimunggul bernama LMDH Wana Mamkur. LMDH Wana Makmur dibentuk dan dilegalkan pada tanggal 22 September 2006 dengan akta notaris No. 55 oleh Lestari Widodo Wilujeung, S.H.Dengan telah dilegalkannya LMDH tersebut maka maka petani yang telah menjadi anggota LMDH harus mematuhi dan melaksanakan semua kewajiban yang telah disepakati dalam perjanjian kerjasama tersebut.

Anggota LMDH Wana Makmur saat ini berjumlah 1.049 orang. Jumlah anggota tersebut mengalami pertambahan dibandingkan tahun sebelumnya.Berikut tabel jumlah anggota LMDH Wana Makmur.

Tabel 2.

Jumlah Anggota LMDH Wana Makmur

\begin{tabular}{llllll}
\hline \multicolumn{5}{c}{ Tahun } \\
\hline 2010 & 2011 & 2012 & 2013 & 2014 & 2015 \\
728 & 786 & 845 & 916 & 982 & 1.049 \\
\hline
\end{tabular}

Banyaknya petani yang bergabung dalam LMDH karena petani mendapat keuntungan berupa penggarapan lahan yang tidak perlu disewa. Namun jika petani melakukan pemindah tanganan penggarapan lahan hutan mereka cukup memberi biaya ganti rugi kepada petani penggarap sebelumnya dengan biaya lebih murah dibanding membeli lahan pertanian.

\section{Kegiatan dalam Program PHBM} Penentuan Jenis Tanaman Semusim

Untuk Petani. Penentuan jenis tanaman semusim yang akan ditanam oleh petani pada lahan bawah tegakan tanaman hutan dilakukan oleh petani atas izin dari Perhutani. Tanaman semusim yang mendapat ijin adalah tanaman yang tidak akan mengganggu pertumbuhan dan perkembangan tanaman milik Perhutani. Tanaman yang banyak ditanam oleh petani adalah padi, selain semangka, kacang panjang, cabai merah dan timun suri.

Pengamanan Hutan. Kegiatan pengamanan hutan kayu putih ini dilakukan bersama-sama antara Polisi hutan dan petani penggarap. Pengawasan dilakukan oleh 5 orang yang terdiri dari 2 polisi hutan dan 3 orang petani dalam satu petakan. Pengawasan dilakukan sebanyak 3 kali dalam sehari yaitu pagi, sore dan malam hari. Pengawasan ini dilakukan petani secara bergilir dan telah terjadwal, sehingga jika salah satu petani tidak hadir karena berhalangan maka akan digantikan oleh petani lainnya.

\section{Ikut Serta Dalam Berbagai Kegiatan}

Kehutanan Di Lapangan. Kegiatan kehutanan yang dilakukan oleh petani salah satunya yaitu ikut serta dalam penanaman tanaman kayu putih. Dalam penanamannya, petani hanya ditugaskan menanam kayu putih ditempat mereka menggarap. Selain bibit yang disediakan, pengiriman bibit juga dilakukan oleh Perhutani ke lokasi penanaman. Hal itu dilakukan agar petani tidak mengalami kesulitan dalam membawa bibit ke lokasi penanaman.

\section{Karakteristik Petani}

Umur. Berdasarkan analisis tabel frekuensi diperoleh bahwa petani yang berusia produktif ada $75 \%$, sedangkan petani yang berusia non-produktif berjumlah 25\%. Berikut tabel karakteristik petani berdasarkan umur selengkapnya.

Tabel 3.

Karakteristik Petani Berdasarkan Umur

\begin{tabular}{|c|c|c|}
\hline $\begin{array}{l}\text { Kelas } \\
\text { (tahun) }\end{array}$ & Umur Frekuensi & $(\%)$ \\
\hline$<15$ & 0 & 0 \\
\hline $15-64$ & 30 & 75 \\
\hline$>64$ & 10 & 25 \\
\hline Total & 40 & 100 \\
\hline
\end{tabular}

Tingkat Pendidikan. Latar belakang pendidikan petani mayoritas adalah tingkatan SD. Namun, cukup banyak juga yang tidak sekolah, yakni mencapai $45 \%$.

Pengalaman Berusahatani Padi gogo. Pengalaman petani dalam berusahatani padi 
gogo di lahan hutan beragam; mulai dari 4 tahun hingga 45 tahun. Hal ini menunjukkan adanya regenerasi petani penggarap dan tingginya minat petani untuk dapat bergabung dalam PHBM. Tabel 5 menggambarkan karakteristik petani dilihat dari pengalamannya. Berdasarkan Tabel 5 tersebut diperoleh rata2-rata lamanya berusahatani adalah 23,8 tahun.

Tabel 4.

Karakteristik Petani Berdasarkan Tingkat Pendidikan

\begin{tabular}{lcc}
\hline Tingkat & Frekuensi & $\%$ \\
Pendidikan & & \\
\hline Tidak Sekolah & 18 & 45 \\
SD & 21 & 52,5 \\
SMP & 1 & 2,5 \\
Total & 40 & 100 \\
\hline
\end{tabular}

Tabel 5.

Karakteristik Petani Berdasarkan Pengalaman Berusahatani Padi Gogo

\begin{tabular}{lcc}
\hline $\begin{array}{l}\text { Lamanya } \\
\text { Berusahatani } \\
\text { (Tahun) }\end{array}$ & Frekuensi & $(\%)$ \\
\hline $4-10$ & 8 & 20 \\
$11-17$ & 6 & 15 \\
$18-24$ & 7 & 17,5 \\
$25-31$ & 9 & 22,5 \\
$32-38$ & 1 & 2,5 \\
$39-45$ & 9 & 22,5 \\
\hline
\end{tabular}

Tabel 6.

Karakteristik Petani Berdasarkan Luas Lahan Garapan

\begin{tabular}{ccc}
\hline Luas lahan (ha) & Frekuensi & $(\%)$ \\
\hline$<0,5$ & 4 & 10 \\
$0,5-1$ & 28 & 70 \\
$>1$ & 8 & 20 \\
Total & 40 & 100 \\
\hline
\end{tabular}

Luas Lahan Garapan. Mayoritas petani $(70 \%)$ menguasai lahan garapan kayu putih seluas 0,5-1 ha. Menurut Hernanto (1989: 46), jika petani yang memiliki penguasaan lahan $\geq 1$ ha maka dikategorikan petani berlahan luas. Jika 0,5-1 ha, petani berlahan sedang. Sedangkan jika $<0,5$ ha, maka petani dikategorikan sebagai petani berlahan sempit. Berikut tabel karakteristik petani berdasarkan luas lahan garapan.

\section{Keragaan Usahatani Padi Gogo.}

Keragaan usahatani padi gogo merupakan suatu sistem agribisnis padi gogo dimana dimulai dari subsistem pengadaan dan penyaluran sarana produksi, subsistem produksi atau usaha tani, subsistem pengolahan hasil-hasil pertanian, hingga subsistem pemasaran hasil-hasil pertanian. Pada Tabel 7 dapat dilihat keragaan usahatani padi gogo tersebut di Desa Jatimunggul.

\section{Subsistem Pengadaan Sarana Produksi Pengadaan Benih, Pupuk, dan}

Pestisida. Pengadaan benih untuk padi gogo ini pada umumnya menggunakan varietas unggul IR yang didapatkan dari hasil panen sebelumnya ataupun membeli. Sarana produksi lainnya yang harus diadakan yaitu pupuk dan obat-obatan. Pupuk yang digunakan yaitu Urea dan TSP, sedangkan obat-obatan yang paling banyak digunakan yaitu roundup (obat rumput), abacel (hama kutu), starban (wereng), amistartop (perangsang pertumbuhan, pembungaan dan pembuahan), prevathon (hama putih dan penggerek), dan antracol (obat pengendali jamur). Untuk pengadaannya petani membelinya ke toko pertanian yang berada disekitar Desa Jatimunggul. Namun pada tahun 2014 petani mendapat pupuk bersubsidi dari Perhutani.

Tabel 7.

Keragaan Usahatani Padi Gogo

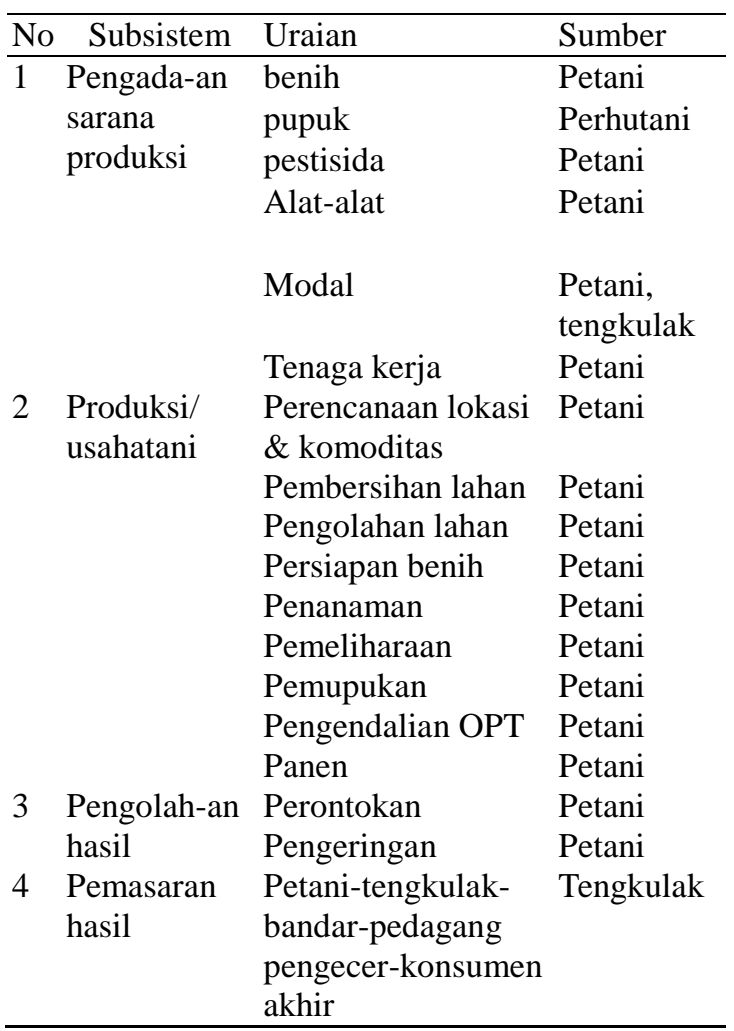


Pengadaan Alat-alat Pertanian. Alatalat pertanian pertanian yang digunakan yaitu cangkul untuk mengolah tanah, tugal untuk melubangi tanah, pedangan untuk memotong rumput dan handsprayer untuk pengendalian hama dan penyakit tanaman. Alat-alat pertanian ini biasanya petani memilikinya sendiri kecuali handsprayer menyewa kepada petani lain dengan harga $\mathrm{Rp} 10.000 / \mathrm{hari}$. Sarana produksi ini bisa dapatkan di pasar ataupun toko-toko pertanian yang berada disekitar Desa Jatimunggul.

Pengadaan Modal. Dalam pengadaan modal, $20 \%$ petani menggunakan modal sendiri dan $80 \%$ petani meminjam kepada tengkulak kecil atau yang biasa disebut dengan colek (istilah petani Jatimunggul) ataupun kepada tetangga dan sanak saudara.

Pengadaan Tenaga Kerja. Jumlah tenaga kerja yang diperlukan terdiri dari 92 orang pria dan 54 orang wanita, yang dirinci dalam 9 kegiatan seperti tampak dalam Tabel 8.

Tabel 8.

Penggunaan Tenaga Kerja per Hektar

\begin{tabular}{lcc}
\hline \multirow{2}{*}{ Kegiatan } & \multicolumn{2}{c}{ Tenaga Kerja (orang) } \\
\cline { 2 - 3 } & Pria & Wanita \\
\hline Membersihkan lahan & 10 & - \\
Pengolahan lahan & 30 & - \\
Penanaman & - & 15 \\
Penyulaman & - & 2 \\
Penyiangan & - & 12 \\
Pemupukan & 4 & - \\
Pengendalian HPT & 21 & - \\
Panen & 25 & 25 \\
Penjemuran & 2 & - \\
Total & 92 & 54 \\
\hline
\end{tabular}

Pekerjaan dengan jumlah tenaga kerja seperti yang tercantum pada Tabel 8 diasumsikan dapat terselesaikan dalam sehari. Tenaga kerja yang digunakan dapat berasal dari dalam maupun luar keluarga.

Upah yang diberikan kepada buruh tani berupa uang tunai dan bagi hasil. Besar upah yang diberikan kepada buruh pria $\mathrm{Rp}$. 60.000/hari dan buruh wanita Rp. 50.000/hari. Waktu kerja mulai dari pukul 7 pagi hingga 12 siang. Upah yang berupa bagi hasil diberikan ketika buruh bekerja pada saat pemanenan. Bagi hasil yang diberikan berupa gabah dengan perhitungan 5 bagian kepada pemilik dan 1 bagian kepada pekerja. Alat yang digunakan untuk bagi hasil gabah dapat berupa baskom ataupun ember cat.

\section{Subsistem Produksi/Usahatani}

Perencanaan Lokasi Dan Komoditas.

Lokasi untuk menanam padi gogo berada di kawasan hutan kayu putih Perhutani. Jarak tanam antar kayu putih adalah 6x1 meter. Hal ini menjadikan lahan diantara tanaman kayu putih tersebut dimanfaatkan untuk usahatani padi gogo. Untuk melindungi tanaman kayu putih agar tidak rusak saat dilakukan pengolahan lahan maka pada tanaman kayu putih dilakukan pembumbunan sehingga membentuk guludan atau bedengan kecil berukuran setengah meter. Komoditas lain yang biasa diusahakan petani yaitu semangka, cabai, ataupun kacang hijau. Namun komoditas tersebut hanya selingan setelah menanam padi.

Pembersihan Lahan. Pembersihan lahan dilakukan dengan menggunakan pedangan. Rumput-rumput yang tumbuh ditebas pendek mendekati pangkal tanam. Setelah rumput ataupun jerami sisa panen yang masih tertanam cukup pendek kemudian petani membakarnya. Posisi tanaman padi yang jauh lebih rendah dibandingkan dengan tanaman kayu putih, mengakibatkan tanaman kayu putih tetap aman walaupun pembersihan dilakukan dengan cara dibakar.

Pengolahan Lahan. Pengolahan tanah dilakukan satu atau dua kali setelah hujan. Sistem pengolahan tanah yang dilakukan petani yaitu sistem pengolahan tanah sempurna (OTS) atau disebut juga sistem olah tanah konvensional. Pada olah tanah sempurna, tanah diolah beberapa kali. Di Jatimunggul, petani yang menggarap lahan di kawasan hutan melakukan 2 kali pengolahan tanah.

Persiapan Benihl. Benih yang digunakan oleh petani diperoleh dari membeli ataupun hasil panen sebelumnya. Jika benih yang digunakan dari hasil panen sebelumnya haruslah benih yang baik dan berisi bukan benih kosong. Untuk mengetahui apakah benih tersebut kosong atau tidak, petani biasanya memanfaatkan angin untuk menerbangkan benih-benih yang kosong.

Penanaman. Penanaman dilakukan segera setelah tanah selesai diolah. Cara penanaman dilakukan dengan cara di tugal. Penugalan dilakukan menggunakan kayu hingga kedalaman $3-5 \mathrm{~cm}$. Untuk tiap lubang ditanam 3-5 butir. Jarak tanam yang digunakan yaitu $20 \times 20 \mathrm{~cm}$. Jumlah benih yang diperlukan sekitar $30 \mathrm{~kg} / \mathrm{ha}$. Setelah 4-5 hari 
penanaman kemudian tanah disemprot dengan roundup (obat rumput).

Pemeliharaan. Penyiangan.

Penyiangan atau petani menyebutnya dengan istilah ngoyos ini dilakukan dengan cara mencabut rumput-rumput yang berada di selasela tanaman. Ngoyos sebaiknya sering dilakukan minimal dimulai pada saat padi berumur 15-20 hari setelah tanam dengan menggunakan cangkul kecil atau dengan tangan hingga tanaman siap panen.

Penyulaman. Penyulaman atau disebut nanjange dilakukan 20 atau 25 hari sebelum tanaman dipupuk dan dilakukan pada saat hujan dengan mengambil dari rumpun yang lebih banyak. Rumpun yang lebih banyak dicabut kemudian dibagi dua dengan kemudian ditanamkan di bagian yang tidak tumbuh.

Pemupukan. Pemupukan atau disebut garem diberikan sebanyak 2 kali berupa pupuk urea dan pupuk TSP. Pemberian pupuk yang pertama sebanyak 4 kuintal/ha pupuk Urea dan TSP pada umur 20 hari dan pemupukan kedua sebanyak 1 kuintal/ha pupuk Urea dan TSP pada umur 60 hari. Pemberian pupuk dilakukan dengan cara disebar dengan menggunakan tangan.

Pengendalian OPT. Petani melakukan pengendalian hama dan penyakit (HPT) dengan menggunakan pestisida seperti Roundup sebagai obat rumput, Abacel sebagai obat kutu, Starban sebagai obat wereng, Amistrostop sebagai obat perangsang pertumbuhan, pembungaan dan pembuahan, Prevathon sebagai obat hama putih dan penggerek dan Antracol sebagai obat pengendali jamur. Pengendalian ini dilakukan dengan penyemprotan yang menggunakan handsprayer. Penyemprotan dilakukan 7 kali yang berselang 7 hari dengan hingga tanaman siap panen.

Panen. Panen padi gogo dilakukan petani ketika usia tanaman siap panen yaitu 105 hari dengan kondisi butir padi yang sudah menguning kurang lebih 90\%-95\%, bagian bawah malai masih terdapat sedikit gabah hijau, kadar air gabah 21-26\%, dan butir hijau rendah.

Panen dilakukan dengan cara memotong bagian bawah batang dengan menggunakan arit. Padi yang telah dipanen kemudian disimpan pada suatu tempat yang telah dialasi terpal. Hasil panen rata-rata padi gogo di Desa Jatimunggul 3-4 ton/ha.
Subsistem Pengolahan Hasil

Perontokan. Cara perontokan yang sebagaian besar secara sederhana namun ada juga dengan mesin perontok. Perontokan secara sederhana dilakukan dengan cara digebot, sedangkan perontokan dengan mesin tergantung keinginan petani dan juga buruh tani. Proses perontokan dilakukan di tempat terbuka dan hanya menggunakan alas terpal tanpa menggunakan dinding sehingga kemungkinan benih terbawa angin dan terlempar sangat besar. Proses perontokan dengan cara digebot ini paling banyak dilakukan hingga 10 gebot namun terkadang kurang dari 10 tergantung dari buruh panen.

Pengeringan. Proses pengeringan dilakukan dengan cara dijemur. Gabah dijemur selama 3-5 hari. Cara pengeringan padi petama yaitu menjemur gabah diatas lantai jemur dengan ketebalan 1-5 cm. Kemudian setiap 1-2 jam sekali atau 4-6 kali dalam sehari dilakukan pembalikan dengan garuk dari kayu. Penjemuran dilakukan dari pagi sampai sore hari hingga kadar air mencapai $14 \%$ atau hingga gabah ketika digigit tidak patah. Setelah gabah kering, kemudian dimasukkan ke dalam karung untuk selanjutnya dijual atau dikonsumsi.

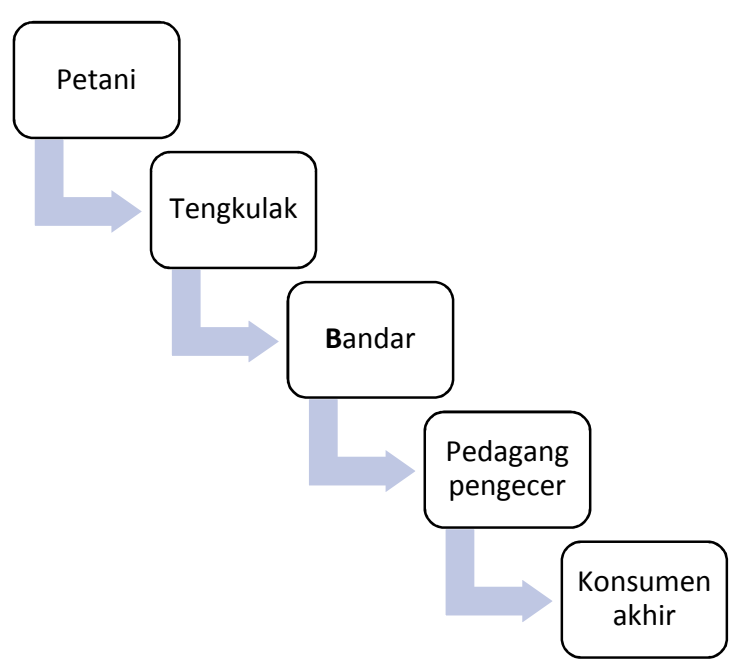

Gambar 1.

Alur Pemasaran Gabah

\section{Subsistem Pemasaran Hasil-hasil}

Usahatani. Petani pada umumnya memasarkan hasil padinya kepada tengkulak. Harga jual padi kepada tengkulak pada musim panen raya jika berupa gabah kering panen (GKP) adalah Rp. 350.000/ku, sedangkan jika gabah kering giling (GKG) adalah Rp. $450.000 / \mathrm{ku}$. Namun demikian sebagian petani 
panen lebih awal sehingga harga jual Rp.550.000/ku GKP. Alur pemasaran gabah padi gogo dilukiskan dalam Gambar 1.

\section{Analisis Usahatani Padi Gogo}

Biaya Usahatani. Biaya usahatani padi gogo terbagi menjadi dua yaitu biaya variabel dan biaya tetap. Biaya yang dikeluarkan untuk satu musim tanam pada rata-rata luas lahan 1 ha adalah Rp. 14.589.450 dimana untuk biaya variabel adalah Rp. 14.589.450 dan untuk biaya tetap adalah Rp. 631.901. Biaya terbesar digunakan untuk biaya tenaga kerja.

Penerimaan Usahatani. Penerimaan usahatani padi gogo terdiri dari penerimaan tunai, penerimaan yang diperhitungkan, dan penerimaan total. Rata-rata penerimaan per satu musim tanam per tahun untuk luas lahan 1 ha yaitu penerimaan tunai Rp. 19.085.000, penerimaan diperhitungkan Rp. 4.715.333 sehingga penerimaan totalnya adalah Rp. 23.800.333 dengan hasil penen GKP sebesar $3.543 \mathrm{~kg} / \mathrm{ha}$. Penerimaan usahatani padi gogo pada program PHBM di Desa Jatimunggul ini lebih besar dibandingkan dengan penerimaan Desa Sukasari, Kecamatan Sukasari, Kabupaten Subang yang memiliki karakteristik iklim yang hampir sama dengan Desa Jatimunggul. Penerimaan Desa Sukasari tahun 2014 yaitu Rp. 13.090.00 per musim tanam per tahun dengan rata-rata produksi padi gogo 2,38 ton/ha. (BPS Kabupaten Subang, 2015). Dengan demikian, penerimaan Desa Jatimunggul adalah Rp. 10.710.333 atau 45\% lebih besar dibandingkan dengan penerimaan Desa Sukasari, sehingga dapat dikatakan usahatani padi gogo pada program PHBM di Desa Jatimunggul memiliki prospek bagus.

Pendapatan Usahatani. Pendapatan terdiri dari pendapatan atas biaya total dan pendapatan atas biaya tunai. Rata-rata pendapatan per satu musim tanam per tahun untuk luas lahan 1 ha yaitu pendapatan atas biaya tunai Rp. 14.671.805 dan pendapatan total Rp. 9.293.985.

Rasio Penerimaan dan Biaya. Rasio penerimaan dan biaya yang biasa disebut dengan rasio $\mathrm{RC}$ digunakan untuk melihat apakah usahatani menguntungkan atau tidak. Rasio ini diperoleh lebih besar dari 1, tepatnya sebesar 1,63. Artinya, usahatani padi gogo di Desa Jatimunggul ini menguntungkan sehingga layak untuk dikembangkan.

Manfaat Kemitraan Dalam PHBM. Berdasarkan temuan diatas maka dapat diketahui manfaat dari adanya Program PHBM yaitu manfaat ekonomi berupa usahatani yang menguntungkan dan manfaat sosial berupa pembukaan lapangan pekerjaan bagi petani maupun buruh tani.

\section{KESIMPULAN}

\section{Kesimpulan}

1. Budidaya padi gogo pada Program PHBM di Desa Jatimunggul masih menggunakan alat-alat pertanian sederhana. Modal diperoleh sebagian besar dari pinjaman ke tengkulak. Proses perencanaan lokasi dan komoditas melibatkan Perhutani serta dalam pemasaran hasil usahatani padi gogo melibatkan tengkulak.

2. Rata-rata penerimaan petani per hektar per musim tanam per tahun adalah Rp. 23.800.333 dimana nilai ini $45 \%$ lebih besar dibandingkan penerimaan usahatani padi gogo di Desa Sukasari, Kabupaten Subang.

3. Usahatani padi gogo menguntungkan. Selain itu, program PHBM memberi manfaat sosial berupa penyediaan lapangan pekerjaan. Dengan demikian, usahatani padi gogo pada Program PHBM di Desa Jatimunggul mempunyai prospek untuk dikembangkan.

\section{DAFTRA PUSTAKA}

Basyir, Amir., Punarto S., Suyamto dan Supriyatin .1995. Padi Gogo. Balai Penelitian Tanaman Pangan Malang, Pusat Penelitian dan Pengembangan Tanaman Pangan, Badan Penelitian dan Pengembangan Pertanian, Malang.

Badan Pusat Statistik Kabupaten Subang, 2015. Kecamatan Sukasari dalam Angka. Dapat diakses di https://subangkab.bps.go.id

Departemen Kehutanan. 2008. Optimalisasi Hutan Untuk Kesejahteraan Rakyat. Available online at: http://simrlps.dephut.go.id (diakses pada 10 September 2015)

Departemen Kehutanan. 2009. Pangan dari Hutan: Kontribusi Sektor Kehutanan dalam Mendukung Ketahanan Pangan Nasional. Available online at: http://www.dephut.go.id/uploads/files/D EPHUT_Makalah_HPS.pdf(diakses pada 3 Desember 2015).

Departemen Pertanian. 1983. Pedoman Bercocok Tanam Padi, Palawija, Sayur- 
Sayuran. Jakarta: Departemen Pertanian.

Fadholi, Hernanto. 1998. Ilmu Usahatani. Jakarta: Penebar Swadaya.

Hilman, V.D dan Kusno, K. 2014. Faktorfaktor yang Dipertimbangkan Pondok Pesantren Al-Iittifaq dalam Mengambil Keputusan Berusahatani Asparagus. Prosiding Pembangunan Inklusif di Sektor Pertanian I. Bandung: UNPAD. Nurmala, Tati. 2012. Pengantar Ilmu Pertanian. Yogyakarta: Graha Ilmu. Rodjak, Abdul. 2006. Manajemen Usahatani. Bandung: Pustaka
Soekartawi, 2002. Prinsip-prinsip Dasar Manajemen Pemasaran Hasil-hasil Pertanian: Teori \& Aplikasinya. Jakarta: Rajawali Pers.

Soekartawi, 2005. Agribisnis/ Teori dan Aplikasinya. Jakarta: Raja Grafindo Persada/

Sugiyono. 2011. Metode Penelitian Kuantitatif, Kualitatif dan R\&D. Bandung: Alfabeta. Yuwariah AS, Yuyun. 2015. Potensi Agroforestry Untuk Meningkatkan Pendapatan, Kemandirian Bangsa, dan Perbaikan Lingkungan. Prosiding Seminar Nasional Agroforestry. 